\title{
Is the Spanish Constitutional Court an instrument of the central government against the Autonomous Communities?
}

\author{
Julio López-Laborda ${ }^{\text {a }}$ \\ Fernando Rodrigo a \\ Eduardo Sanz-Arcega ${ }^{\text {b }}$
}

(September 11, 2017)

\begin{abstract}
This paper applies various probit/logit models to a database constructed by the authors, consisting of rulings by the Spanish Constitutional Court (Tribunal Constitucional) resolving positive conflicts of competence between the Central Government and the Autonomous Communities from 1981 to 2014. Our goal is to empirically contrast whether the TC is predisposed to favour the Central Government or if their rulings are determined by other motivations. According to the results we have obtained, the TC does not seem to be an extension in the jurisdictional milieu of the central executive power.
\end{abstract}

Keywords: Central Government, Autonomous Communities, conflicts of competence, Constitutional Court.

J.E.L. classification: $\mathrm{H} 77$.

\footnotetext{
a University of Zaragoza

b University CEU San Pablo
}

Acknowledgements: The authors would like to thank, with the usual clause exempting them from responsibility, the extraordinary access given them by Luis Pomed and Ignacio Martín to work with the databases of the Constitutional Court. We also thank them for their comments and suggestions, as well as José Caamaño, Manuel Contreras, Ángel de la Fuente, Nuno Garoupa, Santiago Lago, Diego López Garrido, Juan Mora-Sanguinetti, Jorge Onrubia, Eva Sáenz, Gemma Sala, and José Tudela. A special mention deserves a referee of the Journal, whose comments, observations and suggestions have allowed us to substantially improve the first version of the paper. Our research benefited from funding from the Government of Aragón-European Regional Development Fund (Public Economics Research Group, Julio López-Laborda and Fernando Rodrigo), and the Spanish Ministry of Economy and Competitiveness, project ECO2016-76506-C4-3-R (Julio López-Laborda). A version of this paper was presented at the 23 rd Public Economics Meeting, held in Ourense (Spain) February 4-5, 2016, and at a workshop organized by the Spanish Constitutional Court in Madrid on December 13, 2016. 


\section{Introduction}

One of the most conflictive aspects of the design and functioning of the Spanish Autonomic State is the distribution of competences between the Central Government (hereafter CG) and the Autonomous Communities (Spanish political regions, hereafter ACs). On the one hand, it is claimed there is a need to put an end to the process of attributing competences to the regions; on the other hand, the CG is criticized for interfering in regional competences. And all sides agree that the assignment of competences arising from the Constitution is confusing and unwieldy (Aja, 2014; García Roca, ed., 2014), which in the end also affects how citizens understand and value the functioning of the Autonomic State (López-Laborda and Rodrigo, 2015).

These shortcomings have given rise to numerous conflicts between the CG and the ACs. ${ }^{1}$ When they cannot be solved politically (or the will to do so is lacking), these conflicts are referred to the Constitutional Court (Tribunal Constitucional, hereafter TC), the competent body according both to the Constitution and to the Organic Law 2/1979, October 3rd (hereafter LOTC). Since TC Justices are appointed by central institutions (such as the CG and the National Parliament), nationalist parties governing some regions repeatedly claim that the Court is predisposed to rule in favour of those institutions or, to put it another way, that the TC is an agent of the Central Government to seize control of the Autonomous Communities. In the literature, this is also the hypothesis sustained, among others, by Shapiro (1981, 2002, 2003).

This leads to the question underlying this research: whether the Spanish TC tends to favour CG for political reasons or its behaviour responds to other motivations, including the mere application of laws. This paper hopes to provide an empirical answer to this question. To keep it within manageable limits, the research focuses on "conflicts of competence" stricto sensu, and in particular, on "positive vertical conflicts of competence" governed by Articles 60-67 of the LOTC, which are formalized before the TC when the central (autonomic) government considered that a regulation, resolution or act by an AC (the State) did not respect the order of competences established in the Constitution, the Statutes of Autonomy (the regional Constitutions), and the law. ${ }^{2}$ If the controversial competence were attributed by a law, or a

\footnotetext{
${ }^{1}$ On the "regulatoy inflation" of the Autonomous Communities, see Marcos et al. (2010). López-Laborda and Vallés (2010) analyze the determinants of the regulatory activity of the Autonomous Communities between 1989 and 2001 and show the relevance of some variables, such as the existence of nationalist political parties in regional governments.

2 The "negative conflict of competence" occurs when the CG (the AC) declines jurisdiction to resolve any claim, considering that the competence corresponds to an AC (to the CG or another AC): See Articles 68 -72 LOTC.
} 
regulation with the force of law, the conflict of competences is processed as established for an action of unconstitutionality. ${ }^{3}$

After this introduction, the second section of the paper briefly reviews the literature. Next, the third section presents the database created specifically for this research, containing all the positive conflicts of competence between the CG and the ACs resolved from 1981 to 2014. The fourth and fifth sections specify and estimate various probit/logit models based on the database mentioned above, trying to shed light on the motivations lying behind TC's behaviour. Our conclusion is that we should give a negative answer to the question in the title of this paper: no, the Spanish Constitutional Court does not appear to be an instrument used by Central Government against the Autonomous Communities.

\section{Review of the literature}

The literature has examined in depth all the factors which influence the behaviour, and thus the rulings, of judges and courts (see Halberstam, 2008). Scholars divide the judicial behaviour into three categories: the legal or formalist model, the attitudinal model, and the rational choice or strategic model (Segal and Spaeth, 2002; Epstein, Landes and Posner, 2013). In the legal model, judges mechanically apply and interpret the law in order to find the correct legal answer to a conflict. In the attitudinal model, judicial ruling is determined by judges' ideology and institutional environment. In the rational choice model, actors maximize their satisfaction, subject to exogenous constraints.

With regard to Constitutional Courts, a special reference deserves the strategic approach proposed by Shapiro $(1981,2002,2003)$. According to this author, the Supreme Court is an "agent of the central legislature, policing the member states on its behalf" (Shapiro, 2003, p. 9). Shapiro (1981) argues that "judging, like administering, may be principally designed to hold and exploit the countryside for the central regime" (p. 24), and that "[w] here the judge is a political dependent of the government and is employing a legal rule created by this government [...] the judge becomes a dependent of whichever party the law favors" (p. 67). However, the author also acknowledges that the Constitutional Court cannot systematically favour only one party, for reputational reasons: "Not simply a rhetorical but some degree of real neutrality and

\footnotetext{
${ }^{3}$ For the definition of conflicts of competence and actions of unconstitutionality, see Muñoz Machado (2007: 377 et seq.).
} 
independence in federal conflicts is one of the prerequisites of judicial success" (Shapiro, 2002, p. 167).

The empirical approach we develop in the following sections is aimed to test whether the behaviour of the Spanish Constitutional Court when resolving conflicts of competence between the CG and the ACs is better explained by the Shapiro hypothesis or by other attitudinal, legalist or strategic motivations.

In Spain, there have been scholars of the economic analysis of justice for a long time (e.g., Pastor, 1993; Cabrillo and Fitzpatrick, 2008; Mora-Sanguinetti, 2009), but the specific subject we research here has hardly been treated. The works relating most directly to ours are those by Del Castillo (1987), Sala (2010, 2011) and Garoupa et al. (2013), for Spain, and Dalla Pellegrina and Garoupa (2013), for Italy.

The seminal work of Del Castillo (1987) offers the first evidence of the behaviour of TC Justices. The article analyses their particular opinions in relation to the rulings of the Plenary, from the creation of the Court until December 1985. Based on a descriptive approach, the results suggest the existence of two ideological voting patterns (conservative against progressive Justices), allowing the author to "presume the existence of a certain regularity in the behavioural model of the two groups of Justices, in terms of their opinions" (Del Castillo, 1987, pp. 184-185).

Sala $(2010,2011)$ study the rulings of the TC in relation to territorial disputes between the CG and the ACs, based on the classification of these disputes offered by the Ministry of Public Administrations (2008). The earlier of these works analyses, for the 1981-2003 period, and in descriptive terms, the success rate of the CG and the ACs in relation to the controversies in which they were involved. According to the main result of the paper, in general terms, regions whose legal attitude was more belligerent were attributed a lower rate of success.

Sala (2011), again starting with the exploitation of the classification of territorial disputes provided by the Ministry, and for the period 1980-2008, econometrically estimates the factors affecting the probability of the ruling favouring the CG or the ACs. Based on the results obtained by Sala (2011), if the CG is the plaintiff, its previous success rate in preceding conflicts and a lower regional sensitivity of Justices increase the probability of the CG being favoured by the ruling. The author concludes that Justices' individual preferences would emerge more strongly when the basis for the ruling cannot rest on firm precedents.

Garoupa et al. (2013), for the period 1980-2006, use econometrics to study the factors determining whether a Justice votes in line with the political party that backed their nomination. 
To do this, they analyse the votes of the Justices in a sample of rulings created with the most outstanding cases resolving actions of unconstitutionality. According to their results, the probability of a Justice voting in line with the interests of the party which appointed him increases if that party instigated the legal controversy - at the national or regional level - or if the case was brought by a nationalist government. However, the authors conclude that party interests cannot fully explain Justices' behaviour.

Finally, although for the Italian case, the research closest to ours is the paper by Dalla Peregrina and Garoupa (2013), who econometrically estimate, for the 1998-2009 period, potential variables relating to the legal, attitudinal and strategic models, which might modulate judgements in favour of the CG in conflicts of competence with the Italian regions. The authors find evidence that if the CG brings the suit or the Justice presiding is in line ideologically with the party of the Prime Minister (and there is an ideological majority in the Court in this vein) there is greater probability of the ruling favouring the CG.

As Bednar (2004) and Sala (2014) show, the identification of determinants which can predict to some degree the result of judicial rulings contains clear incentives for modulating the strategic behaviour of agents, especially those of territorial administrations in the case of federal States.

\section{Database. Descriptive analysis}

The database consists of the 365 rulings on positive conflicts of competence between the CG and the ACs from 1981 to 2014. Table 1 reflects the conflicts presented by, and resolved in favour of, each level of government. As the last column of Table 1 shows, regions present nearly three times as many conflicts as the CG. ${ }^{4}$ Figure 1 shows that many conflicts were brought by the CG at the start of the devolution process, but then the number decreases until the early 90s. In the 80s, the ACs presented even more conflicts than the CG. They gradually decreased until 2003, when another period of litigation began.

\footnotetext{
${ }^{4}$ Conflicts shown as filed by "both" correspond to appeals independently brought by the Central Government and the Autonomous Communities and accrued by the TC.
} 
Table 1. Conflicts filed by, and resolved in favour of, each level of government, 1981-2014

(In brackets, unanimous rulings)

FAVOURABLE

TO

\begin{tabular}{|c|c|c|c|c|c|}
\hline \multicolumn{1}{c|}{} & $\begin{array}{c}\text { CENTRAL } \\
\text { GOVERNMENT }\end{array}$ & $\begin{array}{c}\text { AUTONOMOUS } \\
\text { COMMUNITIES }\end{array}$ & BOTH & TOTAL \\
\cline { 2 - 7 } & $\begin{array}{c}\text { CENTRAL } \\
\text { GOVERNMENT }\end{array}$ & $40(38)$ & $36(33)$ & $14(9)$ & $90(80)$ \\
\cline { 2 - 7 } & $\begin{array}{l}\text { FILED } \\
\text { COMTONOMOUS }\end{array}$ & $114(90)$ & $46(43)$ & $101(70)$ & $261(203)$ \\
\cline { 2 - 7 } & BOTH & $4(3)$ & $2(2)$ & $8(7)$ & $14(12)$ \\
\hline TOTAL & $158(131)$ & $84(78)$ & $123(86)$ & $365(295)$ \\
\hline
\end{tabular}

Source: Own elaboration.

Figure 1. Conflicts filed by each level of government, resolved in the 1981-2014 period

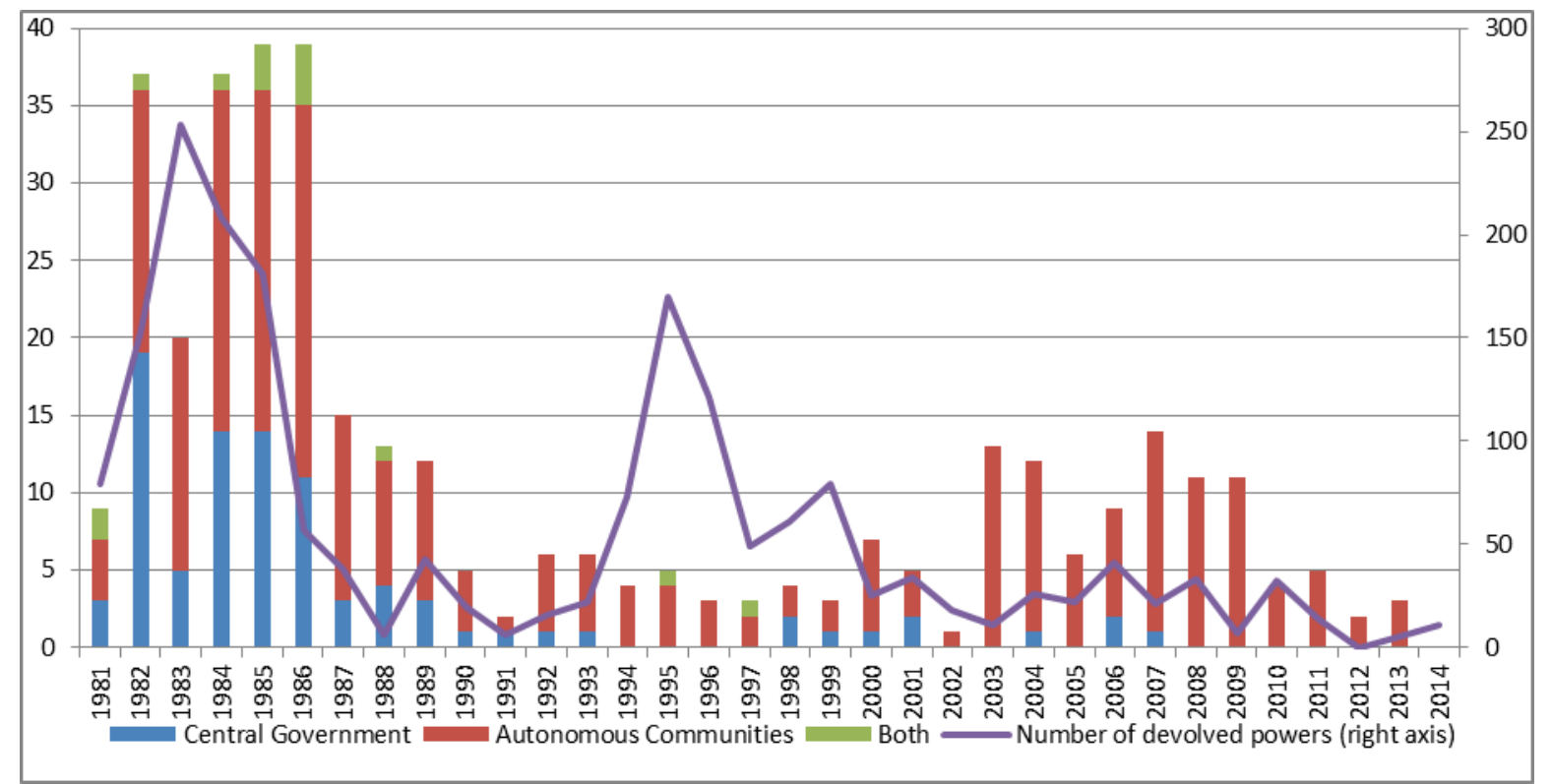

Source: Own elaboration and State Secretariat for Public Administrations (statistics on devolution).

Figure 2 shows that the CG presented conflicts of competence, above all, against Catalonia and the Basque Country. And in Figure 3 we see that, while the Basque Country, like the CG, instigates its conflicts in the $80 \mathrm{~s},{ }^{5}$ Catalonia does so during the entire period of analysis. The conflicts presented by the other Communities evolve in a very similar way as those brought forward by Catalonia. Most positive conflicts of competence against the CG were presented by this region.

\footnotetext{
${ }^{5}$ It should be emphasized that the government of the Basque Country decided not to go to the Constitutional Court from 1990 to 2002: See García Roca (2004: 45). This explains the concentration of conflicts filed by the ACs in the 1980s, which we will take into account in the estimates presented in section 5 of the paper.
} 
Figure 2. Conflicts filed by the Central Government against Catalonia or the Basque Country, resolved in the 1981-2014 period

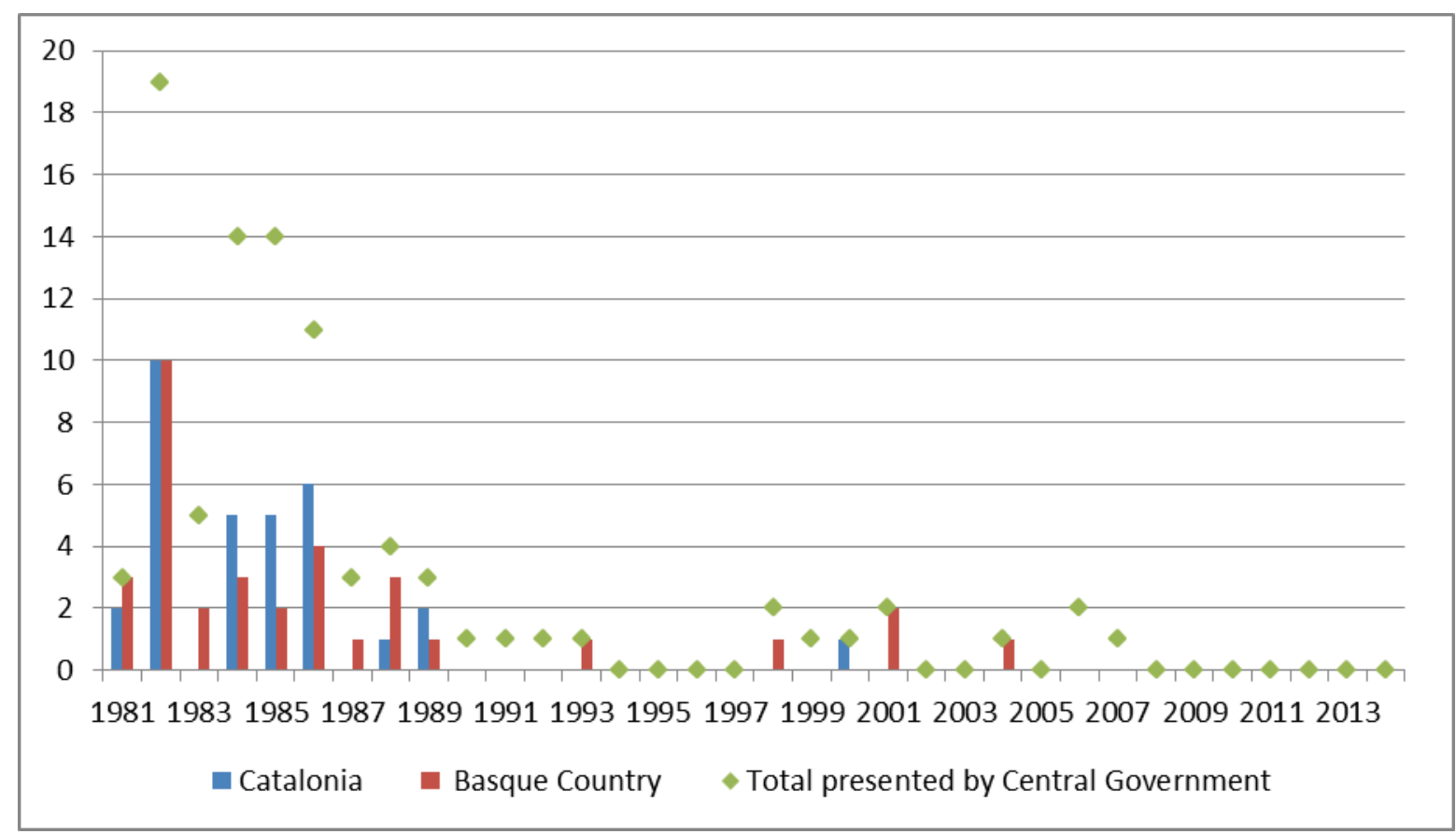

Source: Own elaboration.

Figure 3. Conflicts filed by Catalonia, the Basque Country and the rest of the regions, resolved in the 1981-2014 period

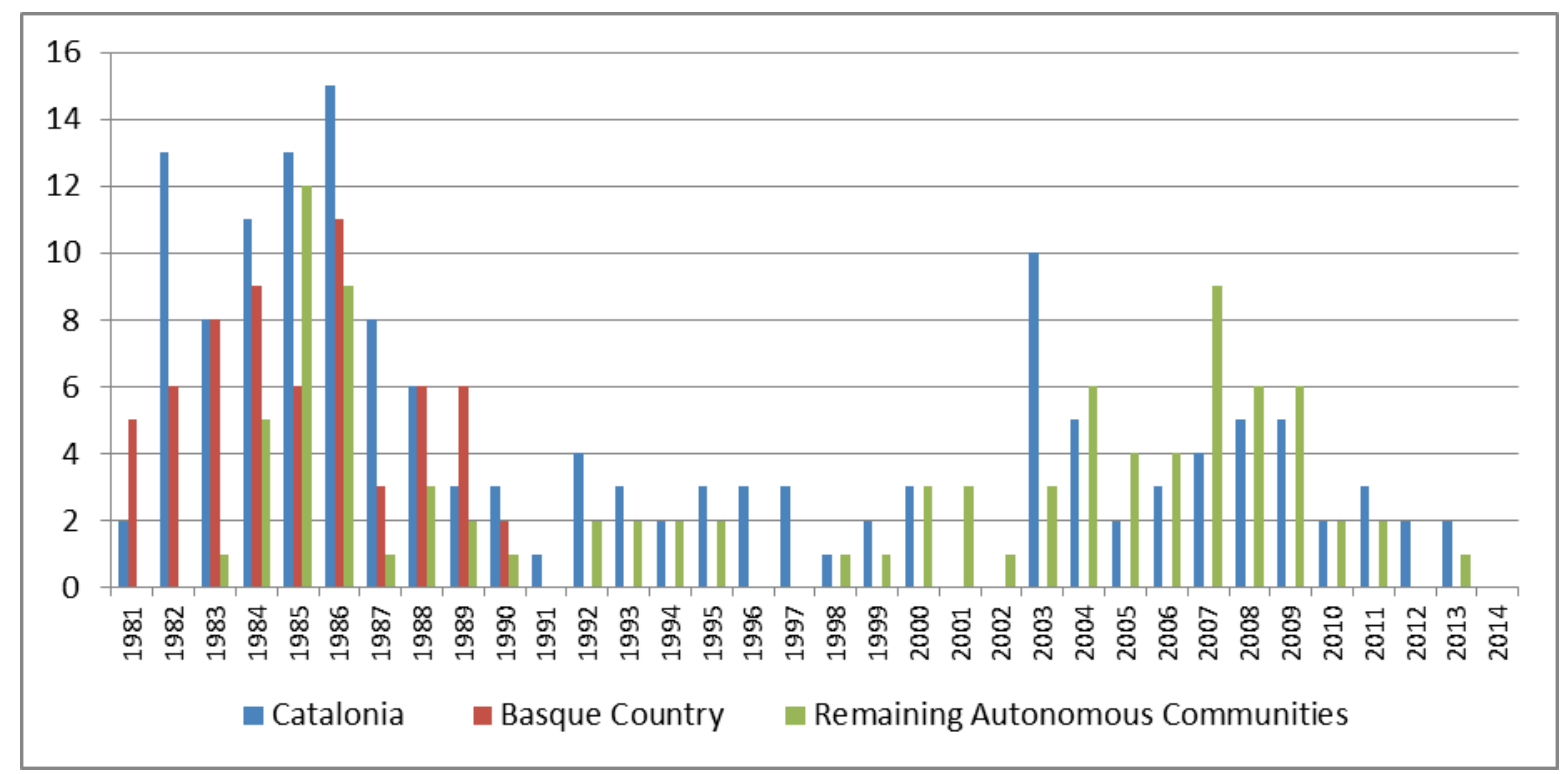

Source: Own elaboration. 
As summarized in the last raw of Table 1, most of the rulings are favourable to the CG and to both levels of administration (i.e., a partially favourable decision). The TC rules in favour of the CG nearly twice as much as in favour of the ACs. As Figure 4 also shows, over time there are fewer rulings in favour of the ACs (correlation time-favourable ruling: -0.54) and more in favour of both governments $(+0.33)$.

Figure 4. Rulings in favour of each level of government, 1981-2014

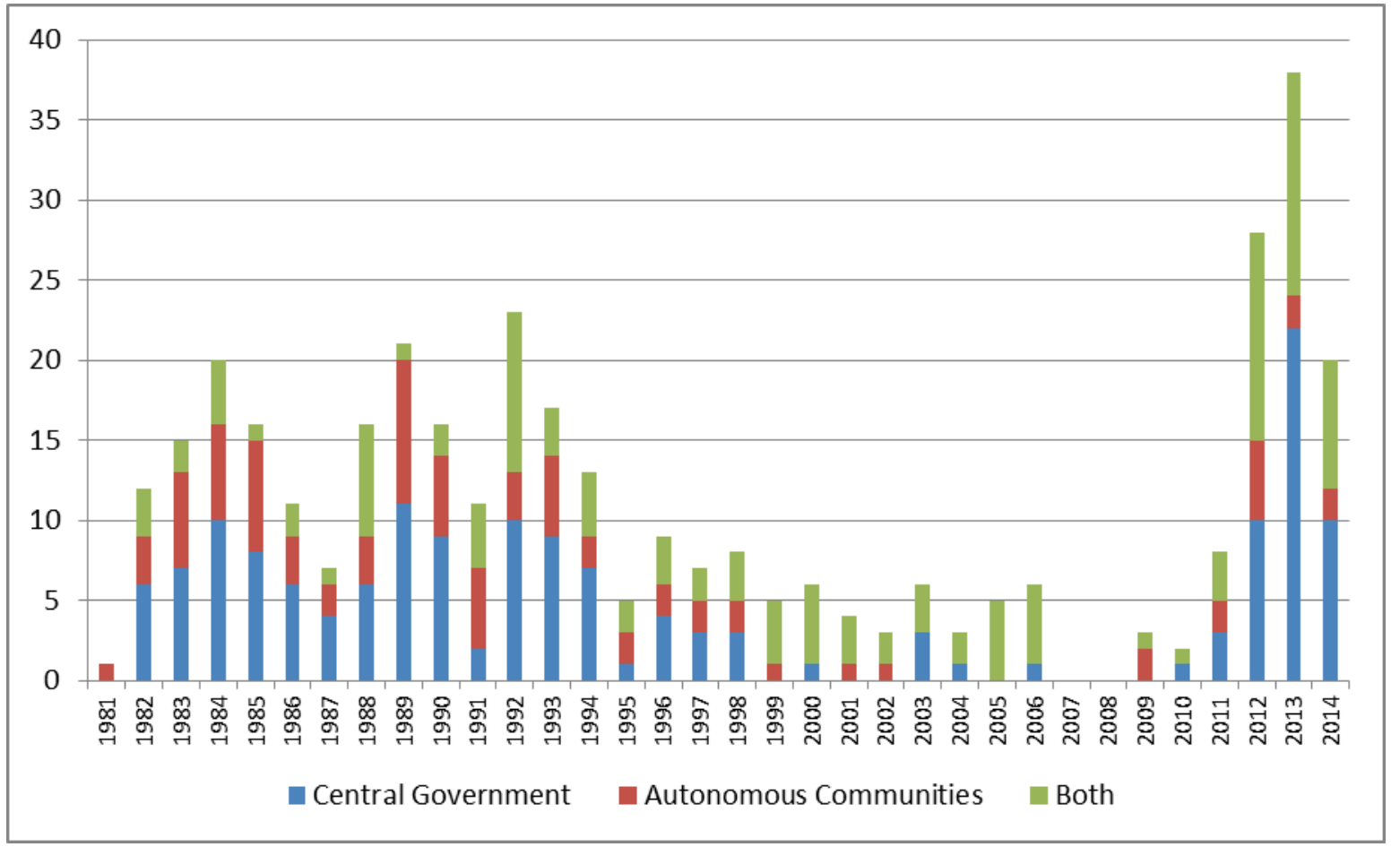

Source: Own elaboration.

Table 1 also shows that TC rules unanimously in favour of the CG nearly $70 \%$ more than in favour of ACs. Over time (Figure 5), there are fewer unanimous rulings in favour of the regions (correlation time-ACs favourable ruling: -0.54$)$ and more in favour of both governments $(+0.17)$. 
Figure 5. Conflicts resolved by unanimous ruling, 1981-2014

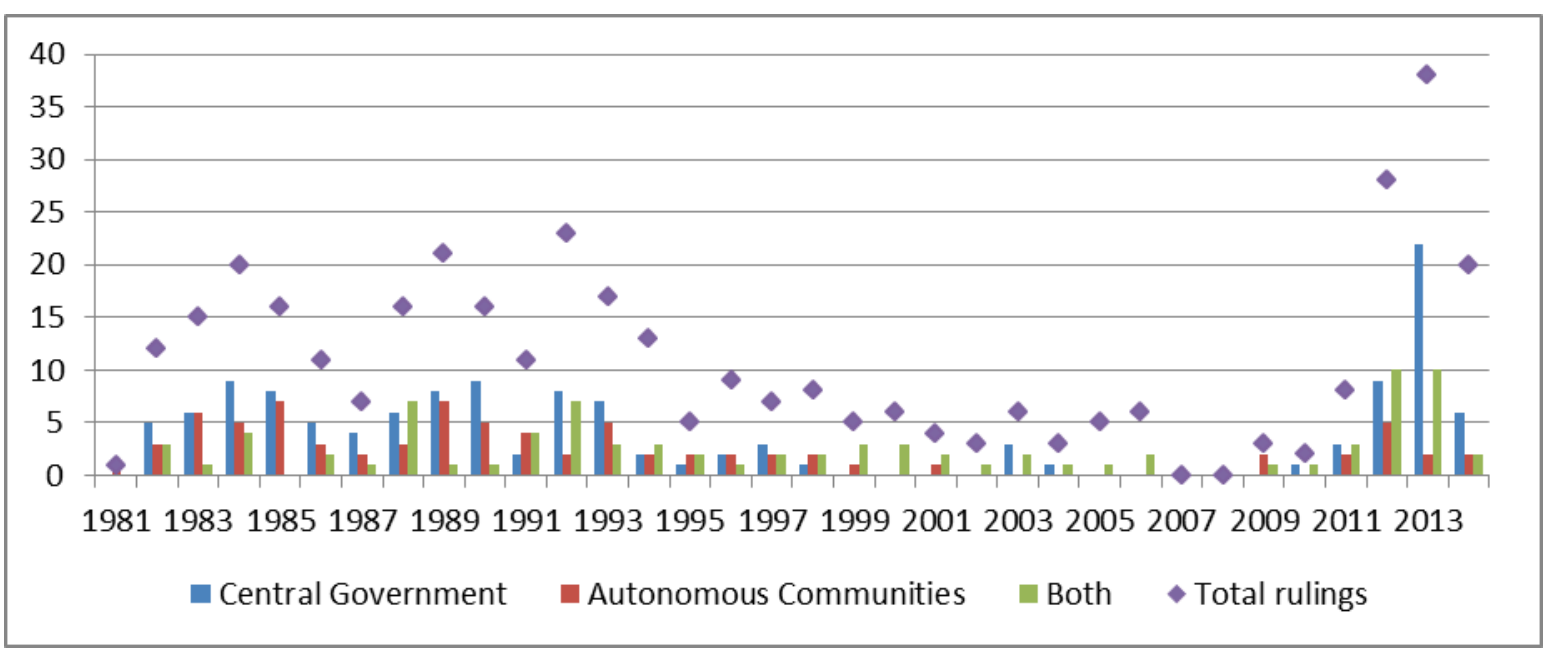

Source: Own elaboration.

Table 1 combines the information provided by the database on the government filing the conflicts and the government which is favoured by the rulings. A re-examination of the table allows us to extend and refine the conclusions drawn from analysing the previous figures.

If the CG presents the conflict, most rulings are in its favour: in $95 \%$ of cases, unanimously. However, there is not much difference regarding rulings in favour of the ACs: 36 compared to 40 , and $92 \%$ unanimously. And there are fewer rulings in favour of the CG than those in favour of the ACs or both administrations: 40 compared to 50 .

If an AC presents the conflict, most rulings are also in favour of the CG: in $79 \%$ of cases, unanimously. Here there is a marked difference from the rulings in favour of the ACs: 46 compared to 114, although there are more unanimous judgements: 93\%. It appears that when regions present a conflict, it is clearer for the TC when they are right, than when the CG or both governments are. There are also fewer rulings in favour of CG than to the ACs or both administrations: 114 compared to 147.

The cases in which conflicts brought by each administration are accrued are not statistically important. But the ones where the ruling is in favour of both governments are important, which happens more when the ACs brought the conflict.

In total, $89 \%$ of the conflicts presented by the CG are resolved unanimously. For conflicts presented by the ACs, the rate is $78 \%$. Conflicts ruled in favour of the CG are resolved unanimously in $83 \%$ of the cases. For conflicts in favour of the ACs, it is $93 \%$. $81 \%$ of all conflicts are resolved unanimously. 
Tables A1, A2, and A3 in the Annex present the same information as Table 1 for Catalonia, the Basque Country and the remaining ACs, respectively. Overall results are, in general, maintained. Furthermore, these Tables clearly show that, regardless of the filer (CG or AC), the TC rules in favour of the CG in a smaller percentage of the conflicts of competence solved if these conflicts affect Catalonia than if they affect other ACs.

Without a more rigorous econometric analysis, the above results could be interpreted as supporting the Shapiro hypothesis as well as other hypotheses. In general, conflicts brought by the CG are mostly ruled in its favour, and almost always unanimously. Those brought by the regions are also mostly ruled in favour of the CG and also, many are in favour of both levels of government. In addition, conflict ruling seems to depend on the affected AC. Do these results mean that the TC is predisposed to support CG's positions, or are there other legalist, strategic or ideological reasons explaining the behaviour of the TC? In the following sections we will try to give an econometric answer to these questions.

\section{Specification}

In this section we are going to test whether the behaviour of the TC is better explained by the Shapiro hypothesis or by an alternative hypothesis. We will formulate these hypotheses as follows:

- Shapiro hypothesis: As the Spanish TC is a body whose members are appointed by central institutions, we would expect a predisposition of the Court to rule in favour of the CG when resolving conflicts of competence with ACs.

- Alternative hypothesis: The behaviour of the TC is explained by other models, such as the attitudinal, the legalist or other strategic ones.

We are interested in explaining the behaviour of the Court as a whole and not that of each of its members. In addition, due to confidentiality we cannot determine how each Justice voted in each ruling; only when they explicitly write or adhere to a particular opinion.

To reach our goal, we have specified and estimated an ordered probit/logit model, in which the endogenous variable $F A V C G$ is a discrete variable which takes three values: 0 , if the ruling is in favour of the AC; 1 , if it favours both levels of governments; and 2, if it is in favour of the CG.

We are not able to construct any explanatory variable whose sign is unambiguously associated to the Shapiro hypothesis, in fact, we think it is impossible to do so. But we can construct variables 
whose sign allow us to accept the alternative hypothesis and, therefore, reject the Shapiro hypothesis. Let us suppose that we construct- as indeed we do- a variable which takes the value 1 if the conflict is brought by the CG and is resolved unanimously, and zero otherwise. A positive sign in the estimated coefficient of this variable does not let us discern whether the TC is behaving according to the Shapiro hypothesis. It might mean that the Court's Justices do support the CG for political reasons, or because its side of the conflict is legally correct. However, the interpretation of a negative sign is clearer. If the fact that the TC unanimously resolves a conflict presented by the CG reduces the probability that the ruling is favourable to this government, this result means we cannot accept the hypothesis that the TC tends to favour the CG.

Taking these cautions into account, we present below all the exogenous variables we have constructed. In the fifth section, we explain the variables that have been included in the final specification. The signs shown would support the alternative hypothesis:

- FILECG: A variable that takes the value 1 if the CG presents the conflict alone, and 0 otherwise. If the CG presenting the conflict reduces the probability of a ruling in its favour (i.e., a negative coefficient is estimated), the alternative hypothesis can be accepted.

- UNAN: A variable which takes the value 1 if the conflict is resolved unanimously, and 0 otherwise. If the fact the conflict was resolved unanimously reduces the probability of the ruling being favourable to CG, this means we can accept the alternative hypothesis (-).

- FILECG*UNAN: A variable resulting from the interaction of the previous two variables (-).

- DIFF*UNAN: A variable resulting from the interaction of DIFF and UNAN, the former being a variable which takes the value 1 if the conflict affects an AC with a different ideology than the CG at the time of the ruling, and 0 otherwise. If the probability of ruling in favour of the CG is reduced when a conflict affects an AC of a different party than the CG, and it is resolved unanimously by Justices with a different ideology, the alternative hypothesis can be accepted (-).

- AGAINSTCAT/AGAINSTBC: Variables which take the value 1 if the CG filed the conflict against Catalonia or the Basque Country, respectively, and 0 otherwise for each of the two cases (-).

- FILECAT/FILEBC: Variables which take the value 1 if the conflict is filed by Catalonia or the Basque Country against the State, respectively, and 0 otherwise for each of the two cases $(-)$. 
- TIME: A variable introduced as a model trend. The passage of time favours having a body of doctrine on the Autonomic State and increasing regional sensitivity by the part of the TC. If the passage of time reduces rulings favourable to the CG, the Shapiro hypothesis cannot be accepted (-).

- CGPP: A variable which takes the value 1 if at the time of the ruling the national government is run by the (right-wing) Partido Popular (PP). We can assume greater awareness and sensitivity to the regions in Spanish left-wing parties, so if the TC rules more in favour of the ACs when the central government is right-wing, we can accept the alternative hypothesis (-).

- IDEOPRESCG: A variable which takes the value 1 if the president of the TC (or the vicepresident, if the president does not participate in the ruling) has the same ideology as the national government at the time of the ruling, and 0 otherwise $(-){ }^{6}$

- IDEORAPCG: A variable which takes the value 1 if the rapporteur has the same ideology as the national government at the time of the ruling, and 0 otherwise (-).

- IDEOTCCG: This variable takes the value 1 if the ideology of the majority of Justices making up the Court at the time of issuing each ruling coincides with that of the CG, and 0 otherwise $(-)^{7}$

- IDEOTCLEFT: A variable which shows the majority ideology of the Justices making up the Court at the time of issuing each ruling, regardless of which ones effectively took part in the deliberations over that ruling. This variable takes the value 1 if the majority is left-wing, and 0 if it is right-wing. We can assume greater awareness and sensitivity to the regions in left-wing Justices, so that if the TC rules more in favour of the ACs when the majority of the TC is right-wing, we can accept the alternative hypothesis $(+)$.

- CGMIN: A variable which takes the value 1 if at the time of the ruling the national government did not have a majority of votes in Parliament and was supported by a Catalan or Basque nationalist party, and 0 otherwise. This was the case in the 5th, 6th, 8 th and 9 th terms of the Spanish Parliament. If the probability of the TC ruling in favour of the CG increases in these periods, the alternative hypothesis can be accepted $(+)$.

- DUMMIES: We have constructed some additional dichotomous variables which take the value 1 from the dates described below:

\footnotetext{
${ }^{6}$ The President (or the Vicepresident if applicable) does have a casting vote.

7 The ideology of the president and Justices of the TC, until 2006, were taken from Garoupa et al. (2013); from that date, from political commentators' consensus expressed on the media.
} 
- According to our data (Figure 1), there is a high rate of conflicts in two periods: 19811989 (CONFL11) and 2003-2009 (CONFL21). The former corresponds with the launch of the Autonomic State (and could be extended until 1992, CONFL12, when the two major national parties reach an agreement ["Acuerdos Autonómicos"] to assign the same responsibilities to all ACs); the latter period corresponds with Prime Minister Aznar's second term (right-wing), and Prime Minister Zapatero's (left-wing) first one (this period could alternatively start in 2000, CONFL22). If in these periods the rulings are more favourable to the ACs, the alternative hypothesis can be accepted $(-)$.

- VAL/CRISIS/CAT: Correspond, respectively, to the ruling of the TC on the Statute of Autonomy of the Autonomous Community of Valencia (12 December 2007), the start of the economic crisis (second quarter of 2008) and the TC ruling on the Statute of Catalonia (27 June 2010). These events are usually associated with a greater pull towards centralisation by the CG. Consequently, if the rulings are more favourable to the ACs after these dates, the alternative hypothesis can be accepted (-).

- REFLOTC*UNAN: In 2007 the Organic Law of the TC (LOTC) was amended, incorporating intervention of the ACs in the nominations of TC Justices proposed by the Senate. The first appointment took place in late December 2010. If after that date there are more unanimous rulings in favour of the CG, the alternative hypothesis can be accepted $(+)$.

- REFFIN*: Variables which correspond to reforms of the regional financing system. We have constructed five dummies (REFFIN1 to REFFIN5), which take the value of 1 during the three years before the approval of the successive reforms of the regional financing system (passed, respectively, on 7 November 1986, 20 January 1992, 23 September 1996, 27 July 2001 and 15 June 2009), and 0 otherwise. We assume that regional financial reforms would have a dampening effect on the demands of the ACs and their conflicts with the CG, but this effect would be expected to weaken over time. Consequently, if in the years before a new reform the TC ruled more against the CG, the alternative hypothesis can be accepted (-).

\section{Estimation and results}

First, we performed an analysis of the correlation between the variables described above. The correlation between some of the explanatory variables is high enough for not accepting the 
complete list in the specification of the model. Our criterion for selection was to eliminate one of the two presenting a positive or negative correlation with an absolute value over 0.5. The descriptive statistics of the selected variables are shown in table 2.

\section{[TABLE 2 ABOUT HERE]}

Thus, the initial specification to be estimated is as follows:

[1] FAVCG $G_{i}=f\left(\begin{array}{l}\text { FILECG }_{i}, \text { DIFF }^{*} \text { UNAN }_{i}, \text { AGAINSTCAT }_{i}, \text { AGAINSTBC }_{i}, \text { FILECAT }_{i}, \text { FILEBC }_{i}, \\ \text { CGPP }_{i}, \text { IDEOTCCG }_{i}, \text { IDEOTCLEFT }_{i}, \text { CGMIN }_{i}, \text { REFFIN }_{i}, \text { REFFIN }_{i}, \\ \text { REFFIN }_{i}, \text { REFFIN }_{i}, u_{i}\end{array}\right)$

Where subscript $i$ corresponds to each ruling resolving a conflict of competence. The hierarchical nature of the values of FAVCG recommends the use of an ordered probit/logit model for estimate this variable, selecting the model with the highest value of the log-likelihood function.

The results of the estimation are presented in Table 3. Together with the estimated value of the coefficient, the value of the marginal effects is offered in case the explanatory variable proves to be significant. We also present the estimate corresponding to a much more stylized model, resulting from a process in which the variables least satisfactory in terms of significance are successively pulled out of the specification described in [1]. We identify this estimation in Table 3 as FAVCG (2).

\section{[TABLE 3 ABOUT HERE]}

Simplified model have lower values in the Akaike (AIC) and Bayesian (BIC) information criteria and also a smaller p-value from the LR Chi-Square test than complete model. Therefore, we will describe the results achieved focusing exclusively on this simplified model.

As Table 3 shows, there are two variables which are found to be significant and with a negative sign: FILECG and FILECAT. So if the conflict is filed by the CG (unlike the results obtained by Sala, 2011 and Dalla Peregrina and Garoupa, 2013) or by Catalonia, this reduces the probability of the ruling being favourable to the CG. As a consequence, the results obtained allow us to reject the hypothesis that the Spanish Constitutional Court is an instrument of Central Government against the Autonomous Communities. Or, in other words, it cannot be ruled out that the behaviour of the TC is better explained by other models.

Among these other models, our estimate rejects both the hypothesis that the TC tends to support the filer (which would require a positive sign for FILECG and a negative one for FILECAT) and the opposite hypothesis that the TC tends to rule against the filer (which would require a negative 
sign for FILECG and a positive one for FILECAT). And we can also reject the hypothesis that the TC is predisposed to rule in favour of ACs (a kind of anti-Shapiro hypothesis). If we jointly read the signs of the variables FILECG and FILECAT, they are telling us that the probability that the TC rules in favour of the GC increases when the conflict of competence is filed by an AC other than Catalonia. As explained in Section 3 above, that is what tables A1 to A3 in the Annex show. The regression analysis does not allow us to identify the reasons lying behind the special result obtained for Catalonia. We do not know whether Catalonia does file cases on a more legal basis than the CG and the remaining regions, whether the TC is predisposed to favour Catalonia or whether there are other strategic or attitudinal motivations explaining TC's behaviour.

In order to check the robustness of the results raised, we have performed some additional estimates. For the sake of simplicity, results are shown in Tables 4 and 5 only for the respective simplified models.

First, specification [1] has been estimated for the alternative endogenous variable FAVCG1, a dichotomous variable which takes the value 1 if the TC rules in favour of the CG, in all or part of the claim, and 0 if not. Since this is a discrete variable, we estimate [1] using probit/logit models, selecting the model with the highest value of the log-likelihood function. As shown in Table 4, we cannot get conclusive results in the estimation of the variable FAVCG1. There are three variables which are found to be significant and with the negative sign associated to the alternative hypothesis: FILECG, DIFF*UNAN, and REFFIN2; but there are also three variables that are significant, with a positive sign: $A G A I N S T B C, C G P P$ and IDEOTCCG. As we remarked above while explaining the construction of the independent variables, this positive sign does not allow us to unambiguously identify the behaviour of the TC. For example, it could be argued that when the CG litigates against the Basque Country Government it does so on a firm legal basis but also that, in this case, the TC tends to favour, at least in part, the interests of the CG. The most we can say is that these results do not support conclusively the hypothesis alternative to that of Shapiro.

Second, we construct a more accurate alternative to the dependent variable than FAVCG1, which we call FAVCG2: it is a dichotomous variable which takes the value 1 only for rulings that are strictly favourable to the CG, and 0 if the TC rules partly or totally in favour of the AC. Equation [1] is again estimated by means of a probit/logit model. The estimate of the simplified model given in Table 4 shows three significant variables with a negative sign, FILECAT, REFFIN4 and REFFIN5, all of then supporting the alternative hypothesis. 


\section{[TABLE 4 ABOUT HERE]}

Third, we have re-estimated specification [1] for the original endogenous variable FAVCG, but only for the sub-samples of rulings affecting Catalonia or Catalonia and the Basque Country, respectively. As explained in section 2, the CG presented conflicts of competence, above all, against Catalonia and the Basque Country (Figure 2), and most conflicts against the CG were presented by Catalonia (Figure 3). The results for these sub-samples are shown in Table 5. In the first case, only the variable $D I F F^{*} U N A N$ is significant and with a negative sign. For the subsample of Catalonia and the Basque Country, in addition to the previous variable, the variable AGAINSTCAT is also significant and with the same negative sign. In short, once again the results achieved allow us to reject the hypothesis that the TC tends to favour CG.

And forth, we have re-estimated specification [1] also for the original variable FAVCG, and for the rulings dictated in the two periods with the greatest levels of conflict between the CG and the ACs (Figure 1): 1981-1990 and 2003-2013. The results of these estimates are shown in Table 5. For the first period, there are two significant variables, FILECG and FILECAT, again with the negative sign that does support the alternative hypothesis.

For the period 2003-2013, there are two variables significant and with the sign associated to the alternative hypothesis: FILECAT (negative) and CGMIN (positive); but there are two other variables also significant and with a positive sign: DIFF*UNAN and CGPP. These results are inconclusive: They do not unambiguously support the alternative hypothesis but neither do they support the Shapiro hypothesis.

\section{[TABLE 5 ABOUT HERE]}

To sum up, we have found enough empirical evidence to reject the hypothesis that the Spanish Constitutional Court is systematically predisposed to rule in favour of the Central Government in the conflicts of competence with the Autonomous Communities. Or, in other words, it cannot be ruled out that the TC's behaviour responds to other motivations, including the mere application and interpretation of the law.

\section{Concluding remarks}

This paper applies various probit/logit models to a self-constructed database, consisting of the 365 rulings by the Spanish Constitutional Court resolving positive conflicts of competence between the Central Government and the Autonomous Communities from 1981 to 2014. Our 
goal was to empirically contrast whether the TC is systematically predisposed to favour the Central Government or if their rulings are determined by other ideological, legal or strategic motivations. According to the results we have obtained, we can state that the TC does not seem to be a mere extension in the jurisdictional milieu of the central executive power.

Conflicts of competence represent only a small part of the disputes between the national government and the Autonomous Communities that end up being judged by the TC (Aja, 2014), and they share some characteristics that should be noted. First, they have a very specific objective: to decide on the ownership or exercise of a competence. Second, as explained in the introduction, conflicts affect regulations, resolutions and acts, but not laws: competence conflicts affecting laws should be treated as acts of unconstitutionality. Although we do not think that these unique features justify differentiated behaviour by the Constitutional Court, we cannot be sure that the results found in this research can be extrapolated to any dispute between the Central Government and the Autonomous Communities. Testing this hypothesis constitutes a logical extension of this work.

\section{References}

Aja, E. (2014): Estado autonómico y reforma federal (Autonomic State and Federal Reform), Madrid: Alianza Editorial.

Bednar, J. (2004): "Judicial Predictability and Federal Stability: Strategic Consequences of Institutional Imperfection", Journal of Theoretical Politics, 16 (4): 423-446.

Cabrillo, F and S. Fitzpatrick (2008): The Economics of Courts and Litigation, Cheltenham, UK: Edward Elgar.

Dalla Pellegrina, L. and N. Garoupa (2013): "Choosing between the government and the regions: An empirical analysis of the Italian Constitutional Court decisions", European Journal of Political Research, 52 (5): 558-580.

Del Castillo, P. (1987): "Notas para el Estudio del Comportamiento Judicial. El Caso del Tribunal Constitucional" (Notes for the Study of Judicial Behaviour. The Case of the Constitutional Court), Revista Española de Derecho Constitucional, 20: 177-191.

Epstein, L., W. M. Landes and R. A. Posner (2013): The Behaviour of Federal Judges. A Theoretical and Empirical Study of Rational Choice, Cambridge, MA: Harvard University Press.

García Roca, J. (2004): "La consolidación de la democracia y justicia constitucionales" (The Consolidation of Constitutional Democracy and Justice), Revista Jurídica de Castilla y León, Número Extraordinario. 25 años de Constitución: lo que nos une: 33-50.

García Roca, J., ed. (2014): Pautas para una reforma constitucional. Informe para el debate (Guidelines for Constitutional Reform. A Report for Discussion), Cizur Menor: Thomson Reuters Aranzadi.

Garoupa, N., F. Gomez-Pomar and V. Grembi (2013): "Judging under Political Pressure: An Empirical Analysis of Constitutional Review Voting in the Spanish Constitutional Court", Journal of Law, Economics, and Organization, 29 (3): 513-534. 
Halberstam, D. (2008): "Comparative Federalism and the Role of the Judiciary", in G. A. Caldeira, R. D. Kelemen and K. E. Whittington, eds., The Oxford Handbook of Law and Politics, Oxford: Oxford University Press.

López-Laborda, J. and F. Rodrigo (2015): "Attribution of regional responsibilities for public services and citizens' support for decentralisation: Evidence for Spain”, Revista Española de Investigaciones Sociológicas, 152: 65-86.

López-Laborda, J. and J. Vallés-Giménez (2010): "Factors explaining the regulatory activity of the Spanish Autonomous Communities", Environment and Planning C: Government an Policy, 28: 469-491.

Marcos, F., J. Santaló and A. Sánchez-Graells (2010): "Measuring regulatory intensity by the Spanish regions (1978-2009)", IE Business School Working Paper, DE8-132-I.

Ministerio de Administraciones Públicas - Ministry of Public Administrations (2008): Base de Datos. Administraciones territoriales (Database. Territorial Administrations). Madrid, MAP-Lexter (CDRom).

Mora-Sanguinetti, J. (2009): "A Characterization of the Judicial System in Spain: Analysis with Formalism Indices", Documento de Trabajo 2009-23, FEDEA.

Muñoz Machado, S. (2007): Derecho Público de las Comunidades Autónomas II (Autonomic Public Law II), 2nd ed., Madrid: Iustel.

Pastor, S. (1993): ;Ab de la justicia!, politica judicial y economía Justice Aboy!, Judicial Politics and Economy), Madrid: Ministry of Justice Publications.

Sala, G. (2010): Can Courts Make Federalism Work?: The Impact of the Constitutional Court on Federal Conflict in Spain, doctoral thesis, Yale University.

Sala, G. (2011): "Courts as Political Institutions with Legal Constraints: Evidence from Spain", work presented at the ECPR General Conference 2011.

Sala, G. (2014): "Can Courts Make Federalism Work? A Game Theory Approach to CourtInduced Compliance and Defection in Federal Systems”, Economies, 2 (193-217).

Segal, J. and H. Spaeth (2002), The Supreme Court and the Attitudinal Model Revisited, New York, NY: Cambridge University Press.

Shapiro, M. (1981): Courts. A Comparative and Political Analysis, Chicago and London: The University of Chicago Press.

Shapiro, M. (2002): "The Success of Judicial Review and Democracy", in M. Shapiro and A. Stone Sweet, On Law, Politics and Judicialization, Oxford: Oxford University Press.

Shapiro, M. (2003): “Judicial review in developed democracies”, Democratization, 10 (4): 7-26. 
Table 2. Basic descriptive statistics of the variables finally used in the specifications of the different models

A) Endogenous variables

\begin{tabular}{||l|r|r|r||}
\hline VARIABLE & FAVCG & FAVCG1 & FAVCG2 \\
\hline Average & 1.20 & 0.77 & 0.43 \\
\hline Median & 1 & 1 & 0 \\
\hline Maximum value & 2 & 1 & 1 \\
\hline Minimum value & 0 & 0 & 0 \\
\hline Standard deviation & 0.79 & 0.42 & 0.50 \\
\hline Coefficient of skewness & -0.37 & -1.28 & 0.27 \\
\hline Coefficient of kurtosis & 1.70 & 2.64 & 1.07 \\
\hline \hline
\end{tabular}

Source: Own elaboration. 
B) Exogenous variables

\begin{tabular}{|c|c|c|c|c|c|c|c|c|c|c|c|c|c|c|}
\hline \begin{tabular}{|l|} 
VARIABLE \\
\end{tabular} & FILECG & $\begin{array}{l}\text { DIFF* } \\
\text { UNAN }\end{array}$ & $\begin{array}{c}\text { AGAINST } \\
\text { CAT }\end{array}$ & AGAINSTBC & $\begin{array}{l}\text { FILE } \\
C A T\end{array}$ & FILEBC & CGPP & $\begin{array}{c}C G \\
M I N\end{array}$ & $\begin{array}{c}\text { IDEO } \\
\text { TCLEFT }\end{array}$ & IDEOTCCG & REFFIN1 & REFFIN2 & REFFIN4 & REFFIN5 \\
\hline Average & 0.25 & 0.63 & 0.09 & 0.09 & 0.41 & 0.17 & 0.36 & 0.14 & 0.76 & 0.59 & 0.12 & 0.13 & 0.04 & 0.02 \\
\hline Median & 0 & 1 & 0 & 0 & 0 & 0 & 0 & 0 & 1 & 1 & 0 & 0 & 0 & 0 \\
\hline $\begin{array}{l}\text { Maximum } \\
\text { value }\end{array}$ & 1 & 1 & 1 & 1 & 1 & 1 & 1 & 1 & 1 & 1 & 1 & 1 & 1 & 1 \\
\hline $\begin{array}{l}\text { Minimum } \\
\text { value }\end{array}$ & 0 & 0 & 0 & 0 & 0 & 0 & 0 & 0 & 0 & 0 & 0 & 0 & 0 & 0 \\
\hline $\begin{array}{l}\text { Standard } \\
\text { deviation }\end{array}$ & 0.43 & 0.48 & 0.28 & 0.29 & 0.49 & 0.38 & 0.48 & 0.34 & 0.43 & 0.49 & 0.33 & 0.34 & 0.19 & 0.15 \\
\hline $\begin{array}{l}\text { Coefficient } \\
\text { of skewness }\end{array}$ & 1.18 & -0.53 & 2.92 & 2.80 & 0.36 & 1.76 & 0.56 & 2.11 & -1.21 & -0.37 & 2.33 & 0.45 & 4.81 & 6.53 \\
\hline $\begin{array}{l}\text { Coefficient } \\
\text { of kurtosis }\end{array}$ & 2.38 & 1.28 & 9.50 & 8.84 & 1.13 & 4.09 & 1.32 & 5.46 & 2.47 & 1.14 & 6.43 & 2.31 & 24.11 & 43.65 \\
\hline
\end{tabular}

Source: Own elaboration. 
Table 3. Results of the ordered probit/logit estimates for FAVCG (whole database)

\begin{tabular}{|c|c|c|c|c|c|c|c|c|}
\hline & \multicolumn{4}{|c|}{$F A V C G$} & \multicolumn{4}{|c|}{$F A V C G(2)$} \\
\hline & coefficient & $\partial P(Y=0) / \partial X_{j}$ & $\partial P(Y=1) / \partial X_{j}$ & $\partial P(Y=2) / \partial X_{j}$ & coefficient & $\partial P(Y=0) / \partial X_{j}$ & $\partial P(Y=1) / \partial X_{j}$ & $\partial P(Y=2) / \partial X_{j}$ \\
\hline FILECG & -0.36 & & & & $-0.48^{* * *}$ & 0.16 & 0.03 & -0.18 \\
\hline DIFF*UNAN & \begin{tabular}{ll|}
-0.04 \\
\end{tabular} & & & & & & & \\
\hline AGAINSTCAT & \begin{tabular}{ll|}
-0.23 \\
\end{tabular} & & & & & & & \\
\hline AGAINSTBC & 0.08 & & & & & & & \\
\hline FILECAT & $-0.31 * *$ & 0.10 & 0.03 & -0.12 & $-0.33^{* *}$ & 0.10 & 0.03 & -0.13 \\
\hline FILEBC & 0.06 & & & & & & & \\
\hline CGPP & 0.30 & & & & & & & \\
\hline IDEOTCLEFT & 0.14 & & & & & & & \\
\hline IDEOTCCG & 0.27 & & & & & & & \\
\hline CGMIN & -0.01 & & & & & & & \\
\hline REFFIN1 & 0.38 & & & & & & & \\
\hline REFFIN2 & \begin{tabular}{ll|}
-0.25 \\
\end{tabular} & & & & & & & \\
\hline REFFIN4 & -0.50 & & & & & & & \\
\hline REFFIN5 & -0.56 & & & & & & & \\
\hline$c_{1}$ (first threshold) & & & & -0.65 & & & & -1.01 \\
\hline$c_{2}$ (second threshold) & & & & 0.29 & & & & -0.08 \\
\hline No. observations & & 365 & & & & & & 365 \\
\hline$L R \chi^{2}$ & & 20.13 & & & & & & 10.22 \\
\hline Prob $>\chi^{2}$ & & 0.1262 & & & & & & 00060 \\
\hline Log-likelihood function & & -379.42 & & & & & & 0.0000 \\
\hline Pseudo $\mathrm{R}^{2}$ of prediction & & 0.0258 & & & & & & -384.37368 \\
\hline & & & & & & & & 0.0131 \\
\hline AIC /BIC & 790. & $425 / 853.2409$ & & & & & & \\
\hline & & & & & & & & 76.7474/792.3469 \\
\hline
\end{tabular}

a The table shows, in the columns, the value of the estimated coefficient of each variable and the marginal effect of the significant variables over the probability that the endogenous variable takes the values 0,1 or 2 . The results correspond to an ordered probit or logit model, attending to the conventional choice of whichever of the two which presents the greater estimated value of the loglikelihood function.

*** Significant coefficient at $1 \%, * *$ significant coefficient at $5 \%, *$ significant coefficient at $10 \%$.

Source: Own elaboration. 
Table 4. Results of the probit/logit estimates for FAVCG1 and FAVCG2 (whole database)

\begin{tabular}{|c|c|c|c|c|}
\hline & \multicolumn{2}{|c|}{ FAVCG1 } & \multicolumn{2}{|c|}{ FAVCG2 } \\
\hline & coefficient & $\partial P(Y=1) / \partial X_{j}$ & coefficient & $\partial P(Y=1) / \partial X_{j}$ \\
\hline FILECG & $-0.67^{* * *}$ & -0.22 & & \\
\hline$D I F F * U N A N$ & $-0.32 *$ & -0.09 & & \\
\hline \multicolumn{5}{|l|}{ AGAINSTCAT } \\
\hline AGAINSTBC & $0.47 *$ & 0.11 & & \\
\hline FILECAT & & & $-0.61 * * *$ & -0.15 \\
\hline \multicolumn{5}{|l|}{ FILEBC } \\
\hline CGPP & $0.40^{* *}$ & 0.11 & & \\
\hline \multicolumn{5}{|l|}{\begin{tabular}{|l} 
IDEOTCLEFT \\
\end{tabular}} \\
\hline IDEOTCCG & $0.36^{* *}$ & 0.11 & & \\
\hline \multicolumn{5}{|l|}{ CGMIN } \\
\hline \multicolumn{5}{|l|}{ REFFIN1 } \\
\hline REFFIN2 & $-0.56^{* *}$ & -0.19 & & \\
\hline REFFIN4 & & & $-2.36^{* *}$ & -0.37 \\
\hline REFFIN5 & & & $-1.81 *$ & -0.32 \\
\hline INTERCEPT & $0.85^{* * *}$ & & 0.06 & \\
\hline No. observations & & 365 & & 365 \\
\hline$L R \chi^{2}$ & & 37.60 & & 21.04 \\
\hline Prob $>\chi^{2}$ & & 0.0000 & & 0.0001 \\
\hline Log-likelihood function & & -178.09776 & & -239.18064 \\
\hline Pseudo $\mathrm{R}^{2}$ of prediction & & 0.0955 & & 0.0421 \\
\hline Percentage of correct predictions by the model & & $77.53 \%$ & & $59.18 \%$ \\
\hline $\mathrm{AIC} / \mathrm{BIC}$ & & $370.1955 / 397.4948$ & & $486.3613 / 501.9609$ \\
\hline
\end{tabular}

a The table shows, in the columns, the value of the estimated coefficient of each variable and the marginal effect of the significant variables over the probability that the endogenous variables take the value 1. The results correspond to an probit or logit model, attending to the conventional choice of whichever of the two which presents the greater estimated value of the log-likelihood function.

*** Significant coefficient at $1 \%, * *$ significant coefficient at $5 \%, *$ significant coefficient at $10 \%$.

Source: Own elaboration. 
Table 5. Additional results of the ordered probit/logit for $F A V E C G^{a}$

\begin{tabular}{|c|c|c|c|c|}
\hline & \multicolumn{4}{|c|}{ FAVCG (2) (subsample of conflicts affecting Catalonia) } \\
\hline & coefficient & $\partial P(Y=0) / \partial X_{j}$ & $\partial P(Y=1) / \partial X_{j}$ & $\partial P(Y=2) / \partial X_{j}$ \\
\hline \multicolumn{5}{|l|}{ FILECG } \\
\hline DIFF*UNAN & $-0.30^{*}$ & 0.09 & 0.03 & -0.11 \\
\hline \multicolumn{5}{|l|}{ AGAINSTCAT } \\
\hline \multicolumn{5}{|l|}{$A G A I N S T B C$} \\
\hline \multicolumn{5}{|l|}{ FILECAT } \\
\hline \multicolumn{5}{|l|}{ FILEBC } \\
\hline CGPP & 0.20 & & & \\
\hline \multicolumn{5}{|l|}{ IDEOTCLEFT } \\
\hline \multicolumn{5}{|l|}{ IDEOTCCG } \\
\hline \multicolumn{5}{|l|}{ CGMIN } \\
\hline \multicolumn{5}{|l|}{ REFFIN1 } \\
\hline \multicolumn{5}{|l|}{ REFFIN2 } \\
\hline \multicolumn{5}{|l|}{ REFFIN4 } \\
\hline \multicolumn{5}{|l|}{ REFFIN5 } \\
\hline$c_{1}$ (first threshold) & & & & -0.88 \\
\hline$c_{2}$ (second threshold) & & & & 0.25 \\
\hline No. observations & & & & 179 \\
\hline$L R \chi^{2}$ & & & & 4.19 \\
\hline Prob $>\chi^{2}$ & & & & 0.1229 \\
\hline Log-likelihood function & & & & -189.94488 \\
\hline Pseudo $\mathrm{R}^{2}$ of prediction & & & & 0.0109 \\
\hline $\mathrm{AIC} / \mathrm{BIC}$ & & & & $.8898 / 400.6393$ \\
\hline
\end{tabular}




\begin{tabular}{|c|c|c|c|c|}
\hline \multicolumn{5}{|l|}{ (Continued) } \\
\hline & \multicolumn{4}{|c|}{ FAVCG (2) (subsample of conflicts affecting Catalonia and Basque Country) } \\
\hline & coefficient & $\partial P(Y=0) / \partial X_{j}$ & $\partial P(Y=1) / \partial X_{j}$ & $\partial P(Y=2) / \partial X_{j}$ \\
\hline \multicolumn{5}{|l|}{ FILECG } \\
\hline$D I F F^{*} U N A N$ & $-0.29 *$ & 0.08 & 0.03 & -0.11 \\
\hline AGAINSTCAT & $-0.47 * *$ & 0.16 & 0.01 & -0.17 \\
\hline \multicolumn{5}{|l|}{$A G A I N S T B C$} \\
\hline FILECAT & -0.24 & & & \\
\hline \multicolumn{5}{|l|}{ FILEBC } \\
\hline \multicolumn{5}{|l|}{ CGPP } \\
\hline \multicolumn{5}{|l|}{ IDEOTCLEFT } \\
\hline \multicolumn{5}{|l|}{ IDEOTCCG } \\
\hline \multicolumn{5}{|l|}{ CGMIN } \\
\hline \multicolumn{5}{|l|}{ REFFIN1 } \\
\hline \multicolumn{5}{|l|}{ REFFIN2 } \\
\hline \multicolumn{5}{|l|}{ REFFIN4 } \\
\hline \multicolumn{5}{|l|}{ REFFIN5 } \\
\hline$c_{1}$ (first threshold) & & & & -1.17 \\
\hline$c_{2}$ (second threshold) & & & & -0.16 \\
\hline No. observations & & & & 249 \\
\hline$L R \chi^{2}$ & & & & 7.26 \\
\hline $\operatorname{Prob}>\chi^{2}$ & & & & 0.0641 \\
\hline Log-likelihood function & & & & -263.78956 \\
\hline Pseudo $\mathrm{R}^{2}$ of prediction & & & & 0.0136 \\
\hline $\mathrm{AIC} / \mathrm{BIC}$ & & & & $7.5791 / 555.1664$ \\
\hline
\end{tabular}




\begin{tabular}{|c|c|c|c|c|}
\hline \multicolumn{5}{|l|}{ (Continued) } \\
\hline & \multicolumn{4}{|c|}{ FAVCG (2) (subsample of rulings in 1981-1990 period) } \\
\hline & coefficient & $\partial P(Y=0) / \partial X_{j}$ & $\partial P(Y=1) / \partial X_{j}$ & $\partial P(Y=2) / \partial X$ \\
\hline FILECG & $-0.94 * * *$ & 0.34 & 0.02 & -0.36 \\
\hline \multicolumn{5}{|l|}{$D I F F^{*} U N A N$} \\
\hline \multicolumn{5}{|l|}{ AGAINSTCAT } \\
\hline \multicolumn{5}{|l|}{ AGAINSTBC } \\
\hline FILECAT & $-0.53^{* *}$ & 0.20 & 0.01 & -0.21 \\
\hline \multicolumn{5}{|l|}{ FILEBC } \\
\hline \multicolumn{5}{|l|}{ CGPP } \\
\hline \multicolumn{5}{|l|}{ IDEOTCLEFT } \\
\hline \multicolumn{5}{|l|}{ IDEOTCCG } \\
\hline \multicolumn{5}{|l|}{ CGMIN } \\
\hline \multicolumn{5}{|l|}{ REFFIN1 } \\
\hline \multicolumn{5}{|l|}{ REFFIN2 } \\
\hline \multicolumn{5}{|l|}{ REFFIN4 } \\
\hline \multicolumn{5}{|l|}{ REFFIN5 } \\
\hline$c_{1}$ (first threshold) & & & & -0.99 \\
\hline$c_{2}$ (second threshold) & & & & -0.51 \\
\hline No. observations & & & & 135 \\
\hline$L R \chi^{2}$ & & & & 14.79 \\
\hline Prob $>\chi^{2}$ & & & & 0.0006 \\
\hline Log-likelihood function & & & & -129.68574 \\
\hline Pseudo $\mathrm{R}^{2}$ of prediction & & & & 0.0540 \\
\hline $\mathrm{AIC} / \mathrm{BIC}$ & & & 267.3 & $715 / 278.9926$ \\
\hline
\end{tabular}




\begin{tabular}{|c|c|c|c|c|}
\hline \multicolumn{5}{|l|}{ (Continued) } \\
\hline & \multicolumn{4}{|c|}{ FAVCG (2) (subsample of rulings in 2003-2013 period) } \\
\hline & coefficient & $\partial P(Y=0) / \partial X_{j}$ & $\partial P(Y=1) / \partial X_{j}$ & $\partial P(Y=2) / \partial X_{j}$ \\
\hline \multicolumn{5}{|l|}{ FILECG } \\
\hline$D I F F * U N A N$ & $0.87^{* *}$ & -0.07 & -0.14 & 0.21 \\
\hline \multicolumn{5}{|l|}{ AGAINSTCAT } \\
\hline \multicolumn{5}{|l|}{ AGAINSTBC } \\
\hline FILECAT & $-1.42^{* * *}$ & 0.12 & 0.21 & -0.33 \\
\hline \multicolumn{5}{|l|}{ FILEBC } \\
\hline CGPP & $1.52^{* * *}$ & -0.17 & -0.15 & 0.33 \\
\hline \multicolumn{5}{|l|}{ IDEOTCLEFT } \\
\hline \multicolumn{5}{|l|}{ IDEOTCCG } \\
\hline CGMIN & $1.74^{*}$ & -0.08 & -0.31 & 0.39 \\
\hline \multicolumn{5}{|l|}{ REFFIN1 } \\
\hline \multicolumn{5}{|l|}{ REFFIN2 } \\
\hline \multicolumn{5}{|l|}{ REFFIN4 } \\
\hline \multicolumn{5}{|l|}{ REFFIN5 } \\
\hline$c_{1}$ (first threshold) & & & & -1.30 \\
\hline$c_{2}$ (second threshold) & & & & 1.32 \\
\hline No. observations & & & & 119 \\
\hline$L R \chi^{2}$ & & & & 15.75 \\
\hline Prob $>\chi^{2}$ & & & & 0.0034 \\
\hline Log-likelihood function & & & & -106.56794 \\
\hline Pseudo $\mathrm{R}^{2}$ of prediction & & & & 0.0688 \\
\hline $\mathrm{AIC} / \mathrm{BIC}$ & & & & $225.1359 / 241.8106$ \\
\hline
\end{tabular}

a The table shows, in the columns, the value of the estimated coefficient of each variable and the marginal effect of the significant variables over the probability that the endogenous variable takes the values 0,1 or 2 . The results correspond to an ordered probit or logit model, attending to the conventional choice of whichever of the two which presents the greater estimated value of the loglikelihood function.

*** Significant coefficient at $1 \%, * *$ significant coefficient at $5 \%, *$ significant coefficient at $10 \%$

Source: Own elaboration. 
Table A1. Conflicts presented by, and resolved in favour of, central government and Catalonia, 1981-2014 (In brackets, unanimous rulings)

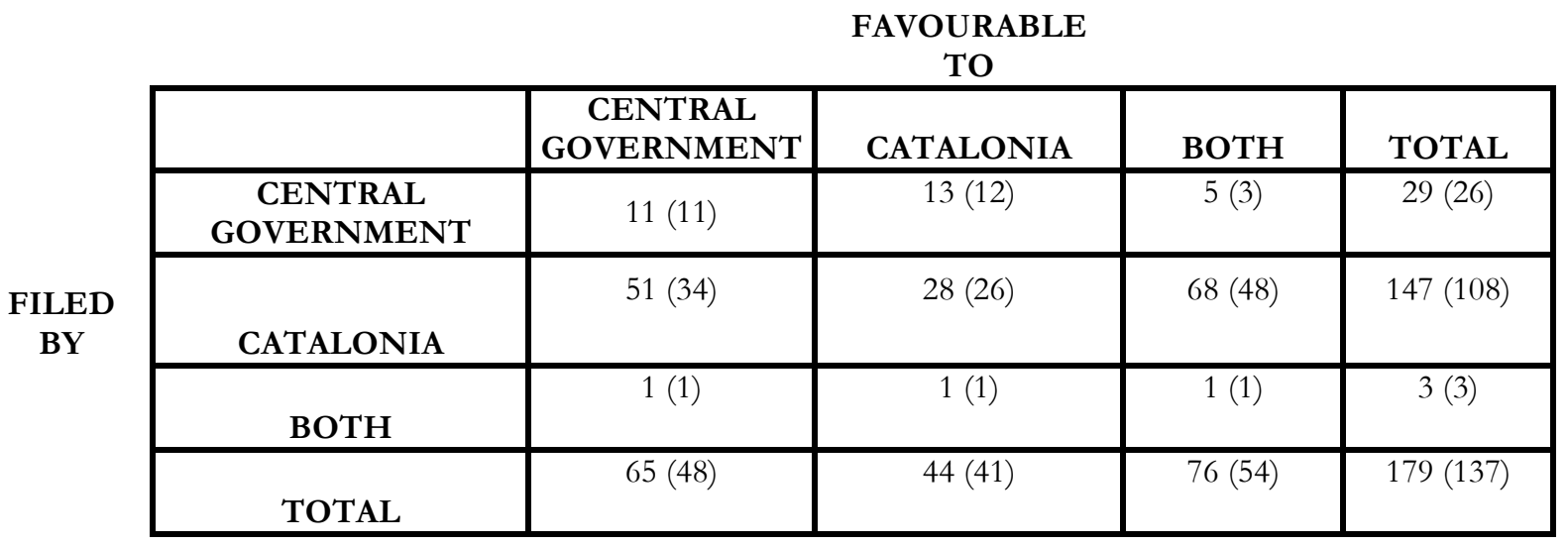

Source: Own elaboration.

Table A2. Conflicts presented by, and resolved in favour of, central government and Basque Country, 1981-2014 (In brackets, unanimous rulings)

\begin{tabular}{|c|c|c|c|c|c|}
\hline & & & $\begin{array}{l}\text { AVOURABL } \\
\text { TO }\end{array}$ & & \\
\hline & & $\begin{array}{c}\text { CENTRAL } \\
\text { GOVERNMENT }\end{array}$ & $\begin{array}{c}\text { BASQUE } \\
\text { COUNTRY }\end{array}$ & ВОТН & TOTAL \\
\hline & $\begin{array}{c}\text { CENTRAL } \\
\text { GOVERNMENT }\end{array}$ & $13(13)$ & $8(8)$ & $6(4)$ & $27(25)$ \\
\hline $\begin{array}{l}\text { FILED } \\
\text { BY }\end{array}$ & BASQUE COUNTRY & $29(24)$ & $11(11)$ & $16(14)$ & $56(49)$ \\
\hline & ВOTH & $1(1)$ & 0 & $5(5)$ & $6(6)$ \\
\hline & TOTAL & $43(38)$ & $19(19)$ & $27(23)$ & $89(80)$ \\
\hline
\end{tabular}

Source: Own elaboration.

Table A3. Conflicts presented by, and resolved in favour of, central government and other Autonomous Communities, 1981-2014 (In brackets, unanimous rulings)

\begin{tabular}{|c|c|c|c|c|c|}
\hline & & & $\begin{array}{c}\text { AVOURABL } \\
\text { TO }\end{array}$ & & \\
\hline & & $\begin{array}{c}\text { CENTRAL } \\
\text { GOVERNMENT }\end{array}$ & $\begin{array}{c}\text { OTHER } \\
\text { REGIONS }\end{array}$ & ВОТН & TOTAL \\
\hline & $\begin{array}{c}\text { CENTRAL } \\
\text { GOVERNMENT }\end{array}$ & $18(15)$ & $15(13)$ & $3(2)$ & $36(30)$ \\
\hline $\begin{array}{l}\text { FILED } \\
\text { BY }\end{array}$ & OTHER REGIONS & $46(41)$ & $12(10)$ & $32(23)$ & $90(74)$ \\
\hline & ВОТН & $1(1)$ & $1(1)$ & $2(1)$ & $4(3)$ \\
\hline & TOTAL & $65(57)$ & $28(24)$ & $37(26)$ & $130(107)$ \\
\hline
\end{tabular}


Source: Own elaboration. 